\title{
Theoretical Perspectives to Diversity in Management Research
}

\author{
Dr. Erhan Aydin \\ Usak University, Turkey \\ E-mail: erhan.aydin@usak.edu.tr
}

Dr. Mushfiqur Rahman

Brunel University London, UK

E-mail: mushfiqur.rahman@brunel.ac.uk

\author{
Received: Feb. 12, $2017 \quad$ Accepted: April 8, $2017 \quad$ Published: April 8, 2017 \\ doi:10.5296/jmr.v9i2.10715 URL: https://doi.org/10.5296/jmr.v9i2.10715
}

\begin{abstract}
The aim of this research is to explore the common theoretical perspectives in diversity research. The need for such a research comes from the lack of literature on understanding and emphasising theoretical differences amongst diversity research based on the focus of the studies that can be either performance or non- performance based. For this reason, having adopted this aim, we discuss the categorisation of "business case for diversity" and "ethical case for diversity" as a comprehensive discussion. Thus, we provided a conceptual contribution to the diversity literature through indicating the need for awareness of research focus.
\end{abstract}

Keywords: Diversity, business case for diversity, ethical case for diversity, managing diversity, diversity research 


\section{Introduction}

Research on diversity in management demonstrates different insights for scholars within the field. Since the research mainly focuses on exploring the role of diversity in organisations, the scholars conduct research regarding organisational performance (Siciliano, 1996), creativity (Vezzali et al., 2016), inclusion and exclusion of minorities such as religion (Uygur and Aydin, 2015) and gender (Aydin, 2016) in relation to diversity. For this reason, the literature fails to categorise the meaning of diversity based on the conducted research. In order to overcome this problematique, we aim at exploring the theoretical perspectives to diversity in management research. Thus, it will be possible to demonstrate philosophical approaches for diversity.

In this paper, based on the positivist and interpretivist studies, we categorise the literature that has performance based and non-performance based research. The concept of performance based studies has been used to point out considering profit as a central goal to conduct diversity research. On the other hand, non-performance based studies demonstrate interpretivist arguments that explore positive or adverse experiences of disadvantageous groups in a diverse environment. This focal point brings the categorisation of "business case for diversity" as utilitarian argument and "ethical case for diversity "as a deontological argument. Following on the demonstrating this diverse pillars of diversity research, we discuss the concept of diversity in management research. In order to achieve aforementioned purpose, we will examine "business case for diversity" and "ethical case for diversity", respectively in order to combine the perspectives in the discussion section.

\section{Understanding “Business Case for Diversity" in Management Research}

The concept of diversity brings a multi-ethnic, multi-racial, and multi-cultural perspective to organisations because that concept creates an awareness of diverse populations both in workplaces and commercial markets. After raising issues of diversity through the Workforce 2000 Report, organisations determined diversity by using a cost-benefit analysis because they believed that diversity provided benefits for businesses (Singal, 2014). This notion brought the idea of the business case for diversity in the 1980s. It was an important realisation in terms of understanding that there is no need to exclude women or ethnic minorities from the workplace, especially since they could provide beneficial business outcomes such as profit and efficient productivity. In addition to these benefits, the common approach towards the business case for diversity was that of providing the inclusion of minorities and the non-discrimination of different identity groups (Kalonaityte, 2010). Some scholars (e.g. Ancona and Caldwell, 1992; Parotta et al., 2012), however, have presented counter-arguments to the business case approach. Therefore, there is no consensus regarding the business case for diversity. Thus, in this section, we firstly discuss mainstream arguments for the business case for diversity's approach, and then secondly, the arguments against such an approach. Fathoming these approaches allows one to better understand the business case for diversity. Based on the various operational ranges of organisations, it is possible to compile business case arguments on three grounds. These are listed as follows: (i) customer relations and market share (Powell and Johns, 2015; Gotsis and Kortezi, 2015a; Gotsis and 
Kortezi, 2015b; Herring, 2009); (ii) labour relations and reducing labour costs (Slatter et al., 2008; Herring, 2009), and (iii) quality and performance of the internal workforce (Ortlieb et al., 2014; Chapple and Humphrey, 2014; Ricco and Guerci, 2014; Robinson and Dechant, 1997). These mainstream arguments have explained the importance of diversity awareness with relation to business profits.

\subsection{Customer Relations and Market Share}

Drawing on data from a national sample of for-profit organisations (National Organization Survey), and based on the testing of eight hypotheses related to the business case for diversity, Herring (2009) posits that diversity contributes to the increase of a company's sales revenues, its attaining more customers, its increasing its market share, and its enjoying greater relative profits. O'Leary and Weathington (2006) also stipulate that employing a diverse workforce leads to companies' having better customer relations. Bendick et al. (2010) explain as well that diversifying a company's workforce leads to the company having better customer relations and a growing market share. According to them, their employees having different life experiences, notions, and cultural backgrounds, in turn, provides their having a better understanding regarding diverse customers because diversity amongst employees creates a broad market in terms of covering the needs of an increasing range of diverse customers. Thus, customer satisfaction has been examined as an important component for obtaining a higher market share. Therefore, some studies (Bhadury et al., 2000; Cox, 1991; Cox and Blake, 1991) specifically focus on creating a relationship between customer satisfaction and market share by employing a diverse workforce.Table 1 . The capitals, assets and revenue in listed banks.

\subsection{Labour Relations and Reducing Labour Costs}

Human capital is a factor that should be considered as being a form of competitive advantage for organisations because it is the collection of all of the intelligence, experience, and insights of organisational members. Within human capital theory, companies try to employ highly skilled people in order to cover their strategic needs - something pivotal for their organisational survival (Wright et al., 2001; Wright et al., 1994) because labour turnovers, absenteeism, and discrimination lawsuits are common problems in companies if they do not have any policies preventing them (Cox, 1991; Morrison, 1992). Therefore, the business case for diversity claims that managing diversity achieves better business results in terms of labour relations and reducing labour costs (Herring, 2009; Niederle et al., 2013; Koys, 2001). The main reason why one should adopt this point-of-view is because it would increase productivity, reduce the turnover rate, and avoid the costs of new recruitments and training (McKay et al., 2009).

\subsection{The Quality and Performance of Internal Workforce}

This dimension of mainstream arguments considers organisational outcomes in terms of profitability, productivity, innovation and group performance (Gotsis and Kortezi, 2013). Businesses have recognised that increasing the creativity and innovation in the workplace is one way of gaining a greater share of the marketplace (Burgess et al., 2009). Robinson and 
Dechant (1997), for example, propose that promoting the business case for diversity is beneficial for businesses because it provides their "improving marketplace understanding, increasing creativity and innovation, producing high quality problem solving, enhancing leadership effectiveness, and building effective global relationships" (Cassell, 2000: 9). The increased quality and performance of the workforce are a part of the indicated results of the business case for diversity. The main points related to this argument are that it: creates a competitive advantage by creating an appropriate corporate image (Nyambegera, 2002); improves group performance at the organisational level (Benschop, 2001; Williams and O'Reilly, 1998); appeals to high quality personnel (Cox and Blake, 1991; Ng and Burke, 2005); increases organisational flexibility by developing problem-solving capabilities at the group level; and encourages creativity and innovation (Cox and Blake, 1991; Milliken and Martins, 1996; Heres and Benschop, 2010). These perspectives of the business case for diversity provides cost reduction, high organisational effectiveness, and increasing business growth and profits (Singh and Point, 2004; Robinson and Dechant, 1997; Heres and Benschop, 2010; Dijk et al., 2012; Thomas and Ely, 1996; O'Leary and Weathington, 2006; Singal, 2014; Ozbilgin, 2008).

In spite of the benefits of the business case for diversity, some scholars emphasise the negative impact that it has on business performance in terms of higher labour turnover; ambiguity; confusion and communication problems; decreased organisational attachment; conflict and tension; and the lack of cohesion amongst the workforce (e.g. Tatli, 2008; Chevrier, 2003; Williams and O'Reilly, 1998; Milliken and Martins, 1996; Nemetz and Christensen, 1996; Cox, 1991.

The main reason for the business case for diversity is the surface-level perspective of managing diversity. This perspective postulates that diversity is an asset and that, therefore, organisations should have a diverse workforce (Dijk et al., 2012). DM and the business case approach to diversity are not as basic as discussed here. For instance, in their critical review of diversity studies, Zanoni et al. (2010) clarify that the business case approach is not sufficient for representing and preserving minority groups because they posit that minority groups have been historically ignored by the business case approach. Furthermore, they claim that there are still prevailing inequalities both in organisations and in society. Noon (2007) supports Zanoni et al.'s (ibid) argument by suggesting that the business case approach does not manage diversity ethically.

As has been stated in this section, the business case for diversity is mainly justified, not only on the grounds of their economic and financial benefits to organisations, but also because they increase companies' competitive advantage in their targeted markets (Morgan and Vardy, 2009). Thus, this perspective regarding the business case is a pragmatic rather than an ethical one. The pragmatic perspective includes the outcomes of businesses which do not have ethical concerns, such as equality and social justice (Gotsis and Kortezi, 2010). Broadly speaking, the deontological and utilitarian paradigms consider these ethical and pragmatic approaches (Ladkin, 2006; Macdonald and Beck-Dudley, 1994). 


\section{Deontological Arguments for Diversity in "Ethical Case for Diversity"}

In this section, we examine the deontological and utilitarian arguments for diversity. In order to do this, we will discuss three deontological approaches to diversity: viz., Kantian deontology, Virtue Ethics, and the Ethics of Care conception of differences. Discussing both arguments for diversity will provide one with a holistic perspective when continuing to discuss diversity issues at different levels of context (i.e. national, international and global).

\subsection{Kantian Deontology}

Kantian deontology examines our actions based on some principles (e.g. being morally right, having good intentions) (Gotsis and Kortezi, 2013). These principles claim that individuals should not consider the consequences of their actions when they adopt those principles. This feature of Kantian deontology emphasises that employees who are in a specific group or minority deserve equality in terms of esteem and respect (Bowie, 1998). This notion does not consider competitive advantage as being determined for the business case for diversity because Kantian deontology posits it prevents pressures, intimidates and manipulates - all of which are unethical in the eyes of Kantian deontology (Ciulla, 2012).

\subsection{Virtue Ethics Views for Diversity}

Utilitarian approach in "business case" examines diversity as a tool which creates opportunity to attain desirable organisational ends. Virtue ethics, on the other hand, depicts organisational virtue - something which is an Aristotelian ethical framework. Aristotle posits the notions of the good life, happiness, and integrity rather than that of the utilitarian's perspective of organisational efficiency (Solomon, 2003; Solomon, 2004, Gotsis and Kortezi, 2013). This ethical view has been indicated as the most convincing one in contrast to rule-based theories of Kantianism and utilitarianism (McPherson, 2013). Also, in McPherson's conceptual paper (2013:288), he emphasises that virtue ethics views regarding businesses encompass 'general justice' (i.e., promoting the common good) and 'practical justice' (i.e., giving what is due to others and avoiding overreaching in benefits for oneself). Thus, he summarises two criteria for virtue ethics in his study as follows:

"The virtues must be exercised (1) for the sake of the good of our lives considered as a unitary whole, and (2) for the common good for communities of which we are a part and the individual good of their members (McPherson, 2013: 289).

Based on McPherson (2013), Gotsis and Kortezi (2013) emphasise that virtues such as forgivingness, meekness and benignity as valued ends; and that they can reduce bias and prevent rigid social categorisation. This provides decreasing the level of stereotypes regarding any type of diversity. Such results of virtue ethics may eliminate the conflicts of employing a diverse workforce.

\subsection{Ethics of Care for Diversity}

This approach is an ethical rationale which encompasses valuing relationships and accepting 
each individual's uniqueness (Wallace et al., 2014). Ethics for care is different from utilitarian and deontological ethics. For instance, whilst utilitarian ethics considers outcomes and cost-benefit analyses for businesses, deontological ethics emphasises universal moral principles in general. However, the ethics for care approach considers the unique abilities of the employees for the purpose of providing an ideal orientation to the organisation (O'Brien, 2013). The approach emphasises that organisations must value each person with his/her own characteristic abilities (Lorbiecki and Jack, 2000; Gotsis and Kortezi, 2013).

The ethical frameworks which are stressed in this section explain why organisations value diversity. The deontological approach considers universal principles and good will. Therefore, that approach emphasises the duties of organisations as creating working environments with regards to universal principles. The utilitarian approach, which supports the business case for diversity, focuses on innovation and better problem solving in order to increase the efficiency of organisational outcomes (Wallace et al., 2014). All approaches mentioned in this section regard how organisations can manage diversity. The perceptions of all arguments mainly focus on for-profit organisations with different organisational ends, such as profit ends and employee-based ends.

\section{Conclusion}

In this conceptual paper, we discussed two different theoretical perspectives to diversity in management research. In order to point out the main features of theoretical perspectives, we categorised them into different sub- sections. Based on the perspectives, the concept of diversity is considered as a tool that either creates positive outcomes for organisations or provides a peaceful environment due to the importance of moral values in life. Even though these two perspectives have different purposes, they all aim at providing inclusion of minorities to the workforce. Whilst some scholars focus on the profit based understanding of organisations, other scholars raise the importance of ethical perspective in organisations. This situation demonstrates that diversity scholars focus on the issues that the organisations care. For instance, if an organisation focuses only on profit, it does not consider the values and ethics. It only considers how profit can be increased. On the other hand, if an organisation realises the importance and impact of society in a context, it focuses on well-being of employees since they need to cover the expectation of society.

\section{Copyright Disclaimer}

Copyright for this article is retained by the author(s), with first publication rights granted to the journal.

This is an open-access article distributed under the terms and conditions of the Creative Commons Attribution license (http://creativecommons.org/licenses/by/3.0/).

\section{References}

Ancona, D. G., \& Caldwell, D. F. (1992). Bridging the boundary: External activity and performance in organizational teams. Administrative science quarterly, 37(4), 634-665. https://doi.org/10.2307/2393475 
Aydin, E. (2016). "Problems and Suggestions": Non-Governmental Organisations of Sexual Orientation Minorities in the context of Turkey and the UK" in Potocan, V., Ungan, M. C. \& Nedelko, Z. (eds), Handbook of Research on Managerial Solutions in Non-Profit Organizations, 232-252

Bendick Jr, M., Lou Egan, M., \& Lanier, L. (2010). The business case for diversity and the perverse practice of matching employees to customers. Personnel Review, 39(4), 468-486. https://doi.org/10.1108/00483481011045425

Benschop, Y. (2001). Pride, prejudice and performance: relations between HRM, diversity and performance. International Journal of Human Resource Management, 12(7), 1166-1181. https://doi.org/10.1080/09585190110068377

Bhadury, J., Mighty, E.J., \& Damar, H. (2000). Maximizing workforce diversity in project teams: a network flow approach. Omega, 28(2), 143-153. https://doi.org/10.1016/S0305-0483(99)00037-7

Bowie, N.E. (1998). A Kantian theory of meaningful work. Journal of Business Ethics, 17(9), 1083-1092. https://doi.org/10.1023/A:1006023500585

Burgess, J., French, E., \& Strachan, G. (2009). The diversity management approach to equal employment opportunity in Australian organisations. The Economic and Labour Relations Review, 20(1), 77-92. https://doi.org/10.1177/103530460902000106

Cassell, C. (2000). The business case and the management of diversity. Women in management: Current research issues, 2, 250.

Chapple, L., \& Humphrey, J.E. (2014). Does board gender diversity have a financial impact? Evidence using stock portfolio performance. Journal of Business Ethics, 122(4), 709-723. https://doi.org/10.1007/s10551-013-1785-0

Chevrier, S. (2003). Cross-cultural management in multinational project groups. Journal of world business, 38(2), 141-149. https://doi.org/10.1016/S1090-9516(03)00007-5

Ciulla, J. (2012). Worthy work and Bowie's Kantian theory of meaningful work. in Arnold, D. and Harris, J. (eds.) Kantian Business Ethics, critical perspectives. Cheltenham: Edward Elgar, 115-131. https://doi.org/10.4337/9781781004968.00013

Cox Jr, T. (1991). The multicultural organization. Academy of Management Executive, 5(2), 34-47. https://doi.org/10.5465/AME.1991.4274675

Cox, T.H., \& Blake, S. (1991). Managing cultural diversity: Implications for organizational competitiveness. Academy of Management Executive, 5(3), 45-56. https://doi.org/10.5465/AME.1991.4274465

Dijk, H., van Engen, M., \& Paauwe, J. (2012). Reframing the business case for diversity: A values and virtues perspective. Journal of Business Ethics, 111(1), 73-84. https://doi.org/10.1007/s10551-012-1434-z 
Dijk, H., van Engen, M., \& Paauwe, J. (2012). Reframing the business case for diversity: A values and virtues perspective. Journal of Business Ethics, 111(1), 73-84. https://doi.org/10.1007/s10551-012-1434-z

Gotsis, G., \& Kortezi, Z. (2013). Ethical paradigms as potential foundations of diversity management initiatives in business organizations. Journal of Organizational Change Management, 26(6), 948-976. https://doi.org/10.1108/JOCM-11-2012-0183

Gotsis, G., \& Kortezi, Z. (2015a). Different Approaches to Managing a Diverse Workforce. in Gotsis, G. and Kortezi, Z. (eds.) Critical Studies in Diversity Management Literature. Springer, 13-21. https://doi.org/10.1007/978-94-017-9475-6_2

Gotsis, G., \& Kortezi, Z. (2015b). The Social Construction of Diversity Discourses: Critical Perspectives on Diversity Management, Power and Inequality. in Critical Studies in Diversity Management Literature. Springer, 45-68. https://doi.org/10.1007/978-94-017-9475-6_4

Gotsis, G. N., \& Kortezi, Z. (2010). Ethical considerations in organizational politics: Expanding the perspective. Journal of Business Ethics, 93(4), 497-517. https://doi.org/10.1007/s10551-009-0241-7

Heres, L., \& Benschop, Y. (2010). Taming diversity: an exploratory study on the travel of a management fashion. Equality, diversity and inclusion: an international journal, 29(5), 436-457. https://doi.org/10.1108/02610151011052762

Herring, C. (2009). Does diversity pay?: Race, gender, and the business case for diversity. American Sociological Review, 208-224. https://doi.org/10.1177/000312240907400203

Kalonaityte, V. (2010). The case of vanishing borders: Theorizing diversity management as internal border control. Organization, 17(1), 31-52. https://doi.org/10.1177/1350508409350238

Koys, D.J. (2001). The effects of employee satisfaction, organizational citizenship behavior, and turnover on organizational effectiveness: A unit-level, longitudinal study. Personnel Psychology, 54(1), 101-114. https://doi.org/10.1111/j.1744-6570.2001.tb00087.x

Ladkin, D. (2006). When deontology and utilitarianism aren't enough: How Heidegger's notion of "dwelling" might help organisational leaders resolve ethical issues. Journal of Business Ethics, 65(1), 87-98. https://doi.org/10.1007/s10551-006-0019-0

Lorbiecki, A., \& Jack, G. (2000). Critical turns in the evolution of diversity management. British Journal of Management, 11(s1), 17-31. https://doi.org/10.1111/1467-8551.11.s1.3

Macdonald, J.E., \& Beck-Dudley, C.L. (1994). Are deontology and teleology mutually exclusive?. Journal of Business Ethics, 13(8), 615-623. https://doi.org/10.1007/BF00871809

McKay, P.F., Avery, D.R., \& Morris, M.A. (2009). A Tale of Two Climates: Diversity Climate From Subordinates'and Managers'perspectives and Their Role in Store Unit Sales 
Performance.

Personnel

Psychology,

$62(4)$

767-791.

https://doi.org/10.1111/j.1744-6570.2009.01157.x

McPherson, D. (2013). Vocational virtue ethics: Prospects for a virtue ethic approach to business. Journal of Business Ethics, 116(2), 283-296. https://doi.org/10.1007/s10551-012-1463-7

Milliken, F.J., \& Martins, L.L. (1996). Searching for common threads: Understanding the multiple effects of diversity in organizational groups. Academy of management review, 21(2), 402-433.

Morgan, J., \& Vardy, F. (2009). Diversity in the Workplace. American Economic Review, 9(1), 472-485. https://doi.org/10.1257/aer.99.1.472

Morrison, A.M. (1992) The New Leaders: Guidelines on Leadership Diversity in America. Jossey-Bass Management Series. ERIC.

Nemetz, P. L., \& Christensen, S. L. (1996). The challenge of cultural diversity: Harnessing a diversity of views to understand multiculturalism. Academy of management review, 21(2), 434-462.

Ng, E. S., \& Burke, R. J. (2005). Person-organization fit and the war for talent: does diversity management make a difference?. The International Journal of Human Resource Management, 16(7), 1195-1210. https://doi.org/10.1080/09585190500144038

Niederle, M., Segal, C., \& Vesterlund, L. (2013). How costly is diversity? Affirmative action in light of gender differences in competitiveness. Management Science, 59(1), 1-16. https://doi.org/10.1287/mnsc. 1120.1602

Noon, M. (2007). The fatal flaws of diversity and the business case for ethnic minorities. Work, Employment \& Society, 21(4), 773-784. https://doi.org/10.1177/0950017007082886

Nyambegera, S.M. (2002). Ethnicity and human resource management practice in sub-Saharan Africa: the relevance of the managing diversity discourse. International Journal of Human Resource Management, 13(7), 1077-1090. https://doi.org/10.1080/09585190210131302

O'Leary, B.J., \& Weathington, B.L. (2006). Beyond the business case for diversity in organizations. Employee Responsibilities and Rights Journal, 18(4), 283-292. https://doi.org/10.1007/s10672-006-9024-9

O'Brien, R. (2013). Bodies in Revolt: Gender Disability and a Workplace Ethic of Care. Routledge.

Ortlieb, R., Sieben, B., \& Sichtmann, C. (2014). Assigning migrants to customer contact jobs: a context-specific exploration of the business case for diversity. Review of Managerial Science, 8(2), 249-273. https://doi.org/10.1007/s11846-013-0106-4 
Ozbilgin, M. (2008). Global Diversity Management. in Smith, P.B., Peterson, M.F. and Thomas, D.C. (eds.) The Handbook of Cross Cultural Management Research. Thousand Oaks: SAGE. https://doi.org/10.4135/9781412982764.n23

Parrotta, Pierpaolo, Pozzoli, Dario, \& Pytlikova, Mariola. (2012). Does labor diversity affect firm productivity?, Discussion Paper Series, Forschungsinstitut zur Zukunft der Arbeit, No. 6973

Powell, M., \& Johns, N. (2015). Realising the Business Case for Diversity: A Realist Perspective on the British National Health Service. Social Policy and Society, 14(02), 161-173. https://doi.org/10.1017/S1474746414000025

Riccò, R., \& Guerci, M. (2014). Diversity challenge: An integrated process to bridge the. implementation gap'. Business Horizons, 57(2), 235-245. https://doi.org/10.1016/j.bushor.2013.11.007

Robinson, G., \& Dechant, K. (1997). Building a business case for diversity. The Academy of Management Executive, 11(3), 21-31. https://doi.org/10.5465/ame.1997.9709231661

Siciliano, J. I. (1996). The relationship of board member diversity to organizational performance. Journal of Business $\quad$ Ethics, 15(12), 1313-1320. https://doi.org/10.1007/BF00411816

Singal, M. (2014). The business case for diversity management in the hospitality industry. International Journal of Hospitality Management, 40, 10-19. https://doi.org/10.1016/j.ijhm.2014.02.009

Singh, V., \& Point, S. (2004). Strategic responses by European companies to the diversity challenge: An online comparison. Long range planning, 37(4), 295-318. https://doi.org/10.1016/j.lrp.2004.05.009

Slater, S. F., Weigand, R. A., \& Zwirlein, T. J. (2008). The business case for commitment to diversity. Business horizons, 51(3), 201-209. https://doi.org/10.1016/j.bushor.2008.01.003

Solomon, R.C. (2003). Victims of circumstances? A defense of virtue ethics in business. Business Ethics Quarterly, 13(01), 43-62. https://doi.org/10.5840/beq20031314

Solomon, R.C. (2004). Aristotle, ethics and business organizations. Organization Studies, 25(6), 1021-1043. https://doi.org/10.1177/0170840604042409

Tatli, A. (2008). Understanding the agency of diversity managers: A relational and multilevel investigation (Doctoral dissertation, Agency of Diversity Managers: A Relational and Multilevel Investigation Ahu Tatli A thesis submitted in partial fulfilment of the requirements of the University of London for the degree of Doctor of Philosophy Queen Mary, University of London).

Thomas, D. A., \& Ely, R. J. (1996). Making differences matter. Harvard business review, 74(5), 79-90. 


\section{Macrothink}

Journal of Management Research

ISSN 1941-899X 2017, Vol. 9, No. 2

Uygur, S., \& Aydin, E. (2015). Religious diversity in the workplace. In J. Syed \& M. Ozbilgin (Ed.), Managing Diversity and Inclusion: An International Perspective (244-264). London, UK: Sage Publication.

Vezzali, L., Gocłowska, M. A., Crisp, R. J., \& Stathi, S. (2016). On the relationship between cultural diversity and creativity in education: The moderating role of communal versus divisional mindset. Thinking Skills and Creativity, 21, 152-157. https://doi.org/10.1016/j.tsc.2016.07.001

Wallace, H., F. Hoover, K., \& B. Pepper, M. (2014). Multicultural ethics and diversity discourse. Equality, Diversity and Inclusion: An International Journal, 33(4), 318-333. https://doi.org/10.1108/EDI-05-2013-0035

Williams, K.Y., \& O'Reilly III, C.A. (1998). A Review of 40 Years of Research. Research in organizational behavior, 20, 77-140.

Wright, P.M., Dunford, B.B., \& Snell, S.A. (2001). Human resources and the resource based view of the firm. Journal of management, 27(6), 701-721. https://doi.org/10.1177/014920630102700607

Wright, P.M., McMahan, G.C., \& McWilliams, A. (1994). Human resources and sustained competitive advantage: a resource-based perspective. International journal of human resource management, 5(2), 301-326. https://doi.org/10.1080/09585199400000020

Zanoni, P., Janssens, M., Benschop, Y., \& Nkomo, S. (2010). Unpacking diversity, grasping inequality: Rethinking difference through critical perspectives. Organization, 17(1), 9-29. https://doi.org/10.1177/1350508409350344 